\title{
PROCEDURAL JUSTICE AND EMPLOYEES' COMMITMENT IN SELECTED HOSPITALS IN RIVERS STATE
}

\author{
Emmanuel Sunny Azubuike ${ }^{1}$ and Dr. Wosu Madubochi ${ }^{2}$ \\ ${ }^{1}$ Department of Sociology, Rivers State University, Port Harcourt, Nigeria \\ Email: sunny.emmanuel@ust.edu.ng \\ ${ }^{2}$ Department of Sociology, Rivers State University, Port Harcourt, Nigeria. \\ Email: madubochi.wosu@ust.edu.ng
}

\section{Cite this article:}

Emmanuel S.A., Wosu M. (2021), Procedural Justice and Employees' Commitment in Selected Hospitals in Rivers State. African Journal of Social Sciences and Humanities Research 4(2), 49-58. DOI: 10.52589/AJSSHREKYD5WID.

\section{Manuscript History}

Received: 19 March 2021

Accepted: 14 April 2021

Published: 3 May 2021

Copyright $\odot 2020$ The Author(s). This is an Open Access article distributed under the terms of Creative Commons Attribution-NonCommercialNoDerivatives 4.0 International (CC BY-NC-ND 4.0), which permits anyone to share, use, reproduce and redistribute in any medium, provided the original author and source are credited.
ABSTRACT: Justice perception can influence employees' attitudes and behaviors for good or bad, and in turn, have a positive or negative impact on the employees' performance and the organization's success. The purpose of this study was to identify the roles of procedural justice toward employee commitment. It also examined the relationship between procedural justice and employee commitment. A convenience sampling was used on the sample size of 200 studied. The results of correlation analysis show that there is a significant positive relationship between procedural justice and employee commitment. The study concludes that employees who perceive unfairness in the workplace may exhibit varying degrees of malicious behaviors. This study provides guidelines for organization management and better ways to reduce employee turnover.

KEYWORDS: Procedural, Justice, Employees and Commitment. 


\section{INTRODUCTION}

It is widely acknowledged that human beings are one of the most important resources for the success of any organization. A happy worker is a self- motivated and productive worker. It also creates resultant effects on the employees' work commitment. Procedural justice is defined as the justice perception of employees related to the methods and processes used during the distribution of organizational outcomes among employees (Greenberg, 1990). In other words, employees' perception of procedural justice is related to the hierarchical level at which organizational outcomes are distributed in accordance with formal organizational procedures, and during the distribution, equitable communication to employees by managers or managers' representatives (Moorman, 1991; Lambert, 2007; Suliman and Kathairi, 2013).

Colquitt (2001) conceptualized the perception of procedural justice as having two partsformal procedures and fair outcomes. The justice of formal procedures concerns employees' perceptions of the fairness of procedures used in the distribution of outcomes. Fair outcomes refer to the level of employees' perceptions of the pre-defined procedures used fairly in the distribution of results. According to Thibaut and Walker (1975), procedural justice has two sub-dimensions. The first of these concerns the structural aspects of methods used in the process of making distributive decisions and practices. This aspect, which is termed legal transactions, includes giving employees the right to speak and utilize their own ideas and approaches during decision making processes. The second aspect of the issue relates to whether decision makers fairly apply the policy and practices during the decision-making process.

\section{Statement of Problem}

Employees are the subjects of decisions virtually every day of their organizational lives (Colquitt, 2001). In organizational settings, justice is not always administered through a fair allocation of employment resources and provision of clear and adequate explanations for decisions made, and employees are not always treated with dignity and respect during the implementation of policies and procedures (Cohen-Charash \& Spector, 2001; Frontela, 2007).

In the case of procedural justice, because it relates to the fairness of the decision-making process surrounding organizational outcomes, how the outcomes are defined is usually more important than the outcomes themselves (DeConinck and Stilwell, 2004). According to CohenCharash and Spector (2001), when employees feel that there has been unjust distribution of organizational outcomes, they first question the procedures which produce the outcomes, and after concluding that the procedures are not fair, they seek to change their performance in order to restore justice in the organization. In this context, procedural justice, similar to distributive justice, affects the emotions, attitudes and behaviors of employees in an organization (CohenCharash and Spector, 2001; Ambrose, 2002). Many studies have been found in the research literature on distributive justice and employee commitment in selected ministries in Rivers State. However, there is no study on the influence of procedural justice on employee commitment among private hospitals in Rivers State.

\section{Research Objectives}

This study was carried out to investigate the influence of procedural justice on employee commitment in private hospitals in Rivers State. The specific objectives are: 
1. To examine the effect of employees' perceptions about procedural justice on employee commitment in selected private hospitals in Rivers State.

2. To determine the effect of procedural justice on the commitment of employees in selected private hospitals in Rivers State.

\section{Research Hypotheses}

The study sought to achieve the research objectives by testing the following hypotheses:

$\mathrm{H}_{0}$ : Perceptions of procedural justice have no significant effect on employee commitment in selected hospitals.

$\mathrm{H}_{0}$ : Procedural justice has no significant effect on employee commitment in selected hospitals in Rivers State.

\section{REVIEW OF RELATED LITERATURE}

Procedural justice is the fairness of the procedures used in the organization used to determine the employees' outcomes (Malik and Naeem, 2011). This justice mainly emphasized the procedures and techniques through which outcomes decisions are made (Ding \& Lin, 2006). Employees perceive the fairness guidelines which are used to make a decision that will lead to crucial outcomes (Bryne, 2005). It is focused on giving employees input into decision making and ensuring fairness by communicating accurately and providing opportunities for rectification. Thus, procedural justice refers to the perceived fairness or equity of the procedures used in making decisions regarding the distribution of rewards, such as promotion. To summarize this paragraph, procedural justice emphasizes the fairness of the procedures used in the organization and the decision making concerning the outcomes. Perceptions of procedural justice are positively related to organizational commitment but not to turnover intentions. The employees will be concerned about the decision process whether it is fair and whether the process used to determine the outcomes is fair and just. Many researchers advocate that greater participation in a pay system will strongly invoke feelings of procedural justice about the system, and this feeling may lead to increased positive personal outcomes, especially job satisfaction and commitment to an organization (Ponnu and Chuah 2010).

Employees, who perceive the process of decision making as unfair in an organization, can never steer the organization to achieve its objectives. Discrimination in decision making has been seen as the main reason why organizations are not able to achieve their objectives. It is important that the manager of an organization ensures that every process is perceived to have been done through procedural justice. Perceptions of unfairness in the organization will lead to psychological stress and real sickness leading to absenteeism and job accidents (Sashkin \& William, 1990).

Procedural justice indicates the fairness of the distribution process through which outcome is allocated (Folger \& Konovsky, 1989). Leventhal $(1976,1980)$ identified six components of a fair process; these are accuracy, lack of bias, consistency, representation of all concerned, correction and ethics. Perception of procedural justice creates an environment of trust, commitment and cooperation among employees (Kim \& Mauborgne, 1991, 1993). Procedural justice exhibits whether organizational policies are equitable to ensure a fair distribution of 
resources among employees (Peele III, 2007). Cropanzano, (2007) stressed that the moral existence of a business enterprise stems from setting a policy that implants a sense of equity and confidence in the minds of the employees.

Masterson, (2000); Cropanzano, (2002); Rupp and Cropanzano, (2002) explained the impact of procedural justice on employee commitment with social exchange theory (Blau, 1964). Social exchange theory sees the organization as an arena in which long term and reciprocal social interactions take place between employees and the organization (Wayne, 1997). Scholars who use social exchange theory explain employee commitment through employees' relationships with both the organization and with the manager (Settoon, 1996; Wayne, 1997). According to these scholars, the factor in employee commitment that will be affected by the relationship between employees and the organization is procedural justice.

Perceptions of procedural justice can convert employees' relationships with organizations from relationships of economic exchange to those of social exchange. Economic exchange relationships are transactional by nature, based on short term interactions and are quid pro quo exchanges (Organ, 1990; Walumbwa et al., 2009). In contrast, social exchange relationships are mostly characterized by such conceptions as identifications shared among employees, loyalty, emotional ties, continuity and mutual support (Organ, 1990; Walumbwa, 2009). In that case, compared to economic exchange relationships, when social exchange relationships occur, employees will display more effective job commitment (Organ, 1990; Settoon, 1996; Walumbwa, 2009). On the one hand, procedural justice perception affects the attitude and behaviors of employees in the organization regarding decisions made by managers, but on the other hand, it carries a symbolic function, such as strengthening the relationship between employees and managers. Therefore, procedural justice, by increasing employees' trust in the manager, organization and organizational commitment, can produce positive organizational results (Greenberg, 1990; Suliman and Kathairi, 2013).

The overall perception of an employee of the employer organizations' HRM practices signifies the employee's subjective belief about an organization's diverse aspects of HRM (Chang, 2005). Applying the social exchange theory, the employment relationship between an employee and an employer can be viewed as a social exchange (Gould-Williams, 2007). The social exchange theory assumes that social exchanges are 'voluntary actions' which create a sense of indebtedness on the part of the recipient to the donor (Paul et al., 2004). Extant literature suggests multiple mechanisms through which HRM practices influence the relationships between justice perceptions and employee commitment. Yeung and Berman (1997) noted that HRM practices aimed at attracting, retaining and motivating employees highly influence employee commitment.

\section{Theoretical Framework}

\section{Procedural Justice Theory}

According to Thibaut and Walker (1975), the amount of control people have over decisions and processes influences their perceptions of fairness. Two types of control exist-process control and decision control. Process control refers to the degree of control people have over the procedures or information used to make a decision. Decision control refers to the degree of control people have over directly determining the outcomes. This theory links people's concern with procedures to their desire to influence their outcomes, and thus defines procedural fairness 
as the level of input or participation that procedures allow in an employment relationship. This is often referred to as the voice factor.

\section{Social Exchange Theory}

The major proponent of social exchange theory is associated with George Homan (1958). The theory proposes that employees exhibit positive or negative behavior as a response to the treatment they receive from their employers. According to Greenberg and Scott (1996), the central aspect of this theory is the norm of reciprocity. A strong exchange relationship between the employer and employee would help maintain a positive working relationship and would elicit positive sentiments such as satisfaction, commitment and trust in employees, which in turn would move employees to engage themselves in employee productivity. Social exchange theory proposes that the relationships we choose to create and maintain are what maximize our rewards and minimize our costs. According to this, we are more self-centered and not necessarily concerned with equality. The basic idea is that relationships that give us the most benefits for the least amount of effort are the ones we value the most and are likely to keep for the long term.

Greenberg and Scott (1996) assert that the exchange theory is most commonly used by the studies in predicting work behavior in the field of organizational behavior. Employers need to treat their employees fairly such that they can reciprocate the good gesture in the form of behavior such as employee commitment, which contributes to organizational success.

The exchange theory also has its fair share of criticism. Miller (2005) argues that the theory reduces human interaction to a purely rational process that arises from economic needs. Miller (2005) further contends that the theory favors openness as it was developed in the 1970s when ideas of freedom and openness were preferred but there may be times when openness is not the best option in a relationship. Exchange theory may provide insight into what variable might mediate the distinct effects of procedural justice on employees' reactions to the organization. Exchange relationships are different from those based on purely economic exchange, in that the obligations to one another are often unspecified and the standards for measuring contributions are often unclear. They develop between two parties through a series of mutualalthough not necessarily simultaneous - exchanges that yield a pattern of reciprocal obligation in each party (Blau, 1964).

One party makes a contribution or provides a service to the other party and in so doing develops an expectation of a return at some future point in time. It is because of this exchange relationship, which exists between the employer and the employee, that exchange theory provides a sound theoretical base for this study.

\section{METHOD}

A cross-sectional study was used for this survey. A self-administered structured survey questionnaire was employed to collect data. The questionnaire contained questions on procedural justice and employee commitment, and a series of demographic questions. It consisted of 21 questions in four sections. The sampling frame was employees who are working in selected private hospitals in Rivers State. A convenience sampling was used. Four private 
hospitals were selected; for each selected hospital, 50 staff were randomly selected. In all, a total of 200 staff participated.

A five-point response was employed, ranging from 1 (strongly disagree) to 5 (strongly agree). In order to facilitate the analysis of the statistics generated from the data, this study employed correlation analyses. The Statistical package for Social Sciences (SPSS) version 20 was used for data analyses.

\section{Result and Discussion}

Research question 1: To examine the effect of employees' perceptions about procedural justice on employee commitment in selected private hospitals in Rivers State.

Table 1: Mean and standard deviation showing employees' perceptions about procedural justice on employee commitment

\begin{tabular}{|l|l|r|r|l|}
\hline S/no & Item & Mean & Std. dev & Decision \\
\hline 1 & $\begin{array}{l}\text { Are all workers treated in the same way } \\
\text { without discrimination? }\end{array}$ & 1.79 & 0.40 & $\begin{array}{l}\text { Not } \\
\text { agreed }\end{array}$ \\
\hline 2 & $\begin{array}{l}\text { Do you give your best and work hard without } \\
\text { prejudice? }\end{array}$ & 1.69 & 0.80 & $\begin{array}{l}\text { Not } \\
\text { agreed }\end{array}$ \\
\hline 3 & $\begin{array}{l}\text { Have you contributed in some way to the } \\
\text { growth of the company without taking into } \\
\text { account the opportunity? }\end{array}$ & 3.00 & 1.02 & Agreed \\
\hline 4 & $\begin{array}{l}\text { To what degree does the company rewards } \\
\text { workers on the basis of their commitment? }\end{array}$ & 3.06 & 0.82 & Agreed \\
\hline 5 & $\begin{array}{l}\text { Will your business provide all workers with the } \\
\text { same compensation? }\end{array}$ & 1.77 & 0.41 & $\begin{array}{l}\text { Not } \\
\text { agreed }\end{array}$ \\
\hline 6 & $\begin{array}{l}\text { Providing employee profit and motivation on } \\
\text { the basis of personal requirements? }\end{array}$ & 3.47 & 0.67 & Agreed \\
\hline
\end{tabular}

Table 1.1 above reveals that the mean values of items 1 and 2 are below the criterion mean 3.0. This is an indication that employees are treated with discrimination. When there is discrimination, employees do not give their best. Respondents agreed that they have been contributing to the growth of their organization without minding the incentive. Employees have always been rewarded based on their contribution. Similar compensation is not provided for all employees.

Research question 2: To determine the effect of procedural justice on commitment of employees in selected private hospitals in Rivers State. 
Table 2: Mean and standard deviation showing procedural justice on commitment of employees in selected private hospitals

\begin{tabular}{|l|l|c|c|c|}
\hline S/no & Item & Mean & Std. dev & Decision \\
\hline 7 & $\begin{array}{l}\text { Providing and communicating reliable decision } \\
\text { making and correlation indicators affect the } \\
\text { engagement of the organization }\end{array}$ & 3.00 & 0.96 & Agreed \\
\hline 8 & $\begin{array}{l}\text { Fairness in performance evaluation plays an } \\
\text { important role in enhancing employee } \\
\text { performance and achieving organizational } \\
\text { objectives }\end{array}$ & 3.42 & 0.90 & Agreed \\
\hline 9 & $\begin{array}{l}\text { Are you satisfied with the evaluation } \\
\text { frameworks used by your organization? }\end{array}$ & 2.30 & 0.23 & $\begin{array}{c}\text { Not } \\
\text { agreed }\end{array}$ \\
\hline 10 & $\begin{array}{l}\text { All employment decisions are uniformly } \\
\text { enforced to all workers affected }\end{array}$ & 3.54 & 0.86 & Agreed \\
\hline 11 & $\begin{array}{l}\text { When decisions are made about my job, my } \\
\text { supervisor considers my viewpoint and treats me } \\
\text { fairly }\end{array}$ & 3.27 & 0.91 & Agreed \\
\hline 12 & $\begin{array}{l}\text { Rewards in this organization are distributed } \\
\text { based on merit }\end{array}$ & 2.40 & 0.23 & $\begin{array}{c}\text { Not } \\
\text { agreed }\end{array}$ \\
\hline
\end{tabular}

Respondents accepted that the availability and exchange of accurate decision making and correlation metrics influence the engagement of the company, the fairness of the performance assessment plays an important role in enhancing the employee's current performance and the achievement of organizational objectives, and all employment decisions are uniformly implemented to all affected employees. Most respondents agreed that when decisions are taken on their work, their boss respects their point of view and treats them equally. Respondents, on the contrary, do not believe that they are pleased with the evaluation process used in their organization. They also disagreed that rewards are distributed based on merit.

$\mathrm{H}_{\mathrm{O} 1}$ : Perceptions of procedural justice have no significant effect on employee commitment in selected hospitals.

Table 3: One sample t-test showing the influence of procedural justice on employee commitment

\begin{tabular}{|l|l|l|l|l|l|c|}
\hline $\mathbf{N}$ & Mean & Std. dev & Df & t-cal & Sig & Decision \\
\hline 200 & 16.10 & 1.59 & 199 & 143.00 & 0.00 & S \\
\hline
\end{tabular}

As shown in table 3, the computed $t$-value of 143.00 was found significant at $p<0.05$ at $\mathrm{Df}=199$. The hypothesis is rejected. In other words, Perceptions of procedural justice have a significant effect on employee commitment.

$\mathrm{H}_{\mathrm{O} 2}$ : Procedural justice has no significant effect on employee commitment in selected hospitals in Rivers State. 
Table 4: One sample t-test showing the influence of procedural justice on employee commitment

\begin{tabular}{|l|l|l|l|l|l|l|}
\hline $\mathbf{N}$ & Mean & Std.dev & Df & t-cal & Sig & Decision \\
\hline 200 & 17.66 & 2.42 & 199 & 102.96 & 0.00 & S \\
\hline
\end{tabular}

As shown in table 4, the computed t-value of 102.96 was found significant at $\mathrm{p}<0.05$ at $\mathrm{Df}=199$. The hypothesis is rejected. In other words, perceptions of procedural justice have a significant effect on employee commitment.

\section{CONCLUSION AND RECOMMENDATION}

Committed workforce is a critical prerequisite for the accomplishment of the organization's strategic objectives. Employees who perceive differences in the workplace can exhibit varying degrees of negative behavior. Employers also need to maintain procedural justice for employees in order to enjoy the benefits of highly committed employees.

When employees have positive opinions on procedural justice, they are likely to have more constructive feelings and more positive attitudes and behaviors towards an organization that has achieved results. This study suggests that organizations promote the commitment of employees by creating terms of employment that are internally commensurate with the contributions of employees and externally competitive. This includes the development of explicit compensation regulations defining the degree to which one is reasonably paid in comparison to peers and the degree to which compensation is increased and distributions are fairly applied.

\section{REFERENCES}

Ambrose, M., Seabright, M. A., \& Schminke, M. (2002). Sabotage in the workplace: The role of organizational injustice. Organizational Behavior and Human Decision Processes.

Blau, P. M. (1964). Exchange and power in social life. New York: Wiley.

Byrne, Z. S. (2005). Fairness reduces the negative effects of organizational politics on turnover intentions, citizenship behavior and job performance. Journal of Business and Psychology, 20(2).

Colquitt, J.A. (2001). On the Dimensionality of Organizational Justice: a Construct Validation of a Measure. Journal of Applied Psychology.

Copranzano, R. Goldman B., \& Benson L., III (2005). Organizational Justice. In J. Barling, K. Kelloway, \& M. Frone (Eds) Handbook of Work Stress. Beverly Hills, CAL Sage.

Crawshaw, J. R., Cropanzano, R., Bell, C. M., \& Nadisic, T. (2013). Organizational justice: New insights from behavioural ethics. Human Relations, 66(7).

Cropanozano R, Goldman B, and Folger R. (2003) Deontic Justice: The role of moral principles in workplace fairness. Journal of organizational behavior, 24, 1019-1024.

Cropanzano, R., Bowen, D. E., \& Gilliland, S.W. (2007). The management of organizational justice. Academy of Management Perspectives, 21(4). 
Cunha, E. P. M., \& Rego, A. (2008), "OCB and Effectiveness: An empirical study in two small insurance companies," The Service Industrial Journal, 28(4), 541-554.

DeConinck, J. B., \& Stilwell, C. D. (2004).Incorporating Organizational Justice, Role States, Pay Satisfaction and Supervisor Satisfaction in a Model of Turnover Intentions.Journal of Business Research, 57(3).

Ding, C. G., \& Lin, C. P. (2006). Comparing the effects of determinants of turnover intentions between Taiwanese and US hospital employees. Human Resource Development Quarterly, 17(4).

Folger, R., \& Konovsky, M. A. (1989). Effects of proce- dural and distributive justice on reaction to pay raise decisions. Academy of Management Journal, 32(1).

Gould-Williams, J., and Davies, F. (2005), 'Using social exchange theory to predict the effects of HRM practice on employee outcomes - An analysis of public sector workers', Public Management Review.

Greenberg, J. (1990) Organizational Justice: Yesterday, Today and Tomorrow,. Journal of Management.

Konovsky, M. A. (2000). Understanding procedural justice and its impact on business organizations. Journal of Management.

Lambert, E. G., Hogan, N. L., \& Griffin, M. L. (2007). The impact of distributive and procedural justice on correctional staff job stress, job satisfaction, and organizatioal commitment. Journal of Criminal Justice.

Leventhal, G. S. (1976). The distribution of rewards and resources in groups and organizations.In L. Berko- witz \& W. Walster (Eds.), Advances in experimental social psychology, 9: 91-131. New York: Academic Press.

Leventhal, G. S. (1980). What should be done with equi- ty theory? New approaches to the study of fairness in social relationships. In K. Gergen, M. Greenberg, \& R. Willis (Eds.), Social exchange: Advances in theory and research. New York: Plenum.

Malik, M. E., Nawab, S., Naeem, B., \& Danish, R. Q. (2010). Job Satisfaction and Organizational Commitment of University Teachers in Public Sector of Pakistan. International Journal of Business and Management.

Masterson, S. S., Lewis, K., Goldman, B. M..\& Taylor, M. S. (2000). Integrating justice and social exchange: The differing effects of fair procedures and treatment on work relationships.Academy of Management Journal.

Moorman, H. R. (1991) Relationship between Organizational Citizenship Behavior and Organizational Justice: Do fairness perception influence employee citizenship?,Journal of Applied Psychology.

Organ, D.W. (1990). The motivational basis of organizational citizenship behavior.In B. M.

Paul, A. K. \& Anantharaman, R. N. (2004). Influence of HRM practices on organizational commitment: A study among software professionals in India. Human Resource Development Quarterly.

Peelle III, H. E. (2007). Reciprocating perceived organi- zational support through citizenship behavior. Journal of Managerial Issues.

Ponnu, C. H., \& Chuah, C. C. (2010). Organizational Commitment, Organizational Justice and Employee Turnover in Malaysia. Afr. J. Bus. Manage.

Rupp, D. E., \& Cropanzano, R. (2002). The mediating effects of social exchange relationships in predicting workplace outcomes from multifoci organizational justice.Organizational Behavior and Human Decision Processes. 
Settoon, R. P., Bennett, N., \& Liden, R. C. (1996). Social exchange in organizations: Perceived organizational support, leader-member exchange, and employee reciprocity. Journal of Applied Psychology.

Staw and L. L. Cummings (Eds.), Research in organizational behavior (Vol.12).

Greenwich, CT : JAI Press.

Suliman, A., \& Kathairi, M.A. (2013).Organizational justice, commitment and performance in developing countries: The case of the UAE. Employee Relations.

Thibaut, J., \& Walker, L. (1975) .Procedural Justice: A Psychological Analysis. Hillsdale: Lawrence Erlbaum.

Walumbwa, F. O., Cropanzano, R., \& Hartnell, C. A. (2009). Organizational justice, voluntary learning behavior, and job performance: A test of the mediating effects of identification and leader-member exchange. Journal of Organizational Behavior.

Wayne, S. J., Shore, L. M., \& Liden, R. C. (1997). Perceived organizational support and leadermember exchange: A social exchange perspective. Academy of Management Journal.

Yeung, K. A. \& Berman, B. (1997). Adding Value through Human Resources: Reorienting Human Resource Measurement to drive Business Performance. Human Resource Management. 